\title{
СРЕДЊОВЕКОВНА ДУХОВНОСТ КАО УПОРИШТЕ ПОСТМОДЕРНОГ ЕНЦИКЛОПЕДИЗМА
}

\begin{abstract}
Полазећи од теоријских разматрања Умберта Ека и Николаја Берђајева у тексту се испитује присуство средњовековне духовности и имагинације у неким од најбољих српских постмодерних романа: Хазарском речнику Милорада Павића, Фами о бициклистима Светислава Басаре, Опсади иркве Светог Спаса Горана Петровића и Савршеном сећању на смрт Радослава Петковића. Иако је однос према средњем веку код сваког од ових аутора различит, он се нипошто не своди на тематско-мотивску раван него открива сложенију поетичку тежњу ка успостављању слике света као смисаоног тоталитета.
\end{abstract}

Кључне речи: постмодернизам, средњи век, роман, енциклопедија, поетика.

Гледано из перспективе просветитељством надахнутих великих прича о друштвеном, технолошком и научном прогресу, средњи и двадесети век су дијаметрално различите, несводљиве епохе на супротним странама могуће лествице напретка. Међутим, уметност двадестога века, поготову његовог постмодерног доба, оспорила је и ову велику причу. Средњовековни свет, духовност и имагинација постали су важно упориште књижевне инспирације новога доба. Заправо, постмодерни енциклопедизам, првенствено онај развијен на поетичкој линији историографске метафикције, има два важна упоришта у епохама средњег века и барока, чему су историчари књижевности, како страни (Велш 2000; Скарпета 2003) тако и наши (Делић 1991), посветили знатну пажњу.

Откуда тај повратак средњем веку? Пишући поводом Џојсових романа о модерној култури, Умберто Еко истиче да је модерност великим делом настала као реакција на хијерархизовану слику света као уређеног космоса, која је свој најпотпунији израз имала у средњовековним сумама, каква су Summa theologica или Summa contra gentiles Томе Аквинског. Међутим, ма колико јој се супротстављала, модерна култура није успела да избегне чари

"pedja611@yahoo.com 
једног реда у којем је све било сврсисходно. Модерно доба се, дакле, успоставља као непрестана тензија између потребе за некавим смисаоним редом и, с друге стране, отворености у авантуру неизвесности. „Сваки пут када смо покушали да ново стање света у којем се крећемо некако дефинишемо, налазиле су нам се у рукама формуле, макар и травестиране, класичног реда" (Еко 1965: 228). Сличан парадокс иманентан је и енциклопедизму, од средњовековних сума до постмодерног романа. Свеукупност знања којој се читалац радо предаје, запрво је илузија које на крају постаје свестан. Али без те тензије између фрагмената и целине, бесконачности света и ограничености знања, складности поретка и његовог сталног нарушавања кроз отворености за нова читања, енциклопедијског наратива не би ни било.

Екова инспирација средњим веком потврдиће се не само у његовом најпознатијем роману, Име руже, него и у монографији Бескрајни спискови, посвећеној управо енциклопедијској парадигми која се у уметности испољава на различите начине још од Хомеровог и библијског доба а понајпре кроз каталоге, спискове, реторику набрајања, односно оно што Еко назива поетиком „свеукупног укључивања” која тежи да свет представи као уређени или, пак, привидно хаотични тоталитет. Наравно, и пре овог италијанског књижевника многи аутори су указивали на „звездано небо” средњовековне епохе. Ипак, неће сви имати подједнаки утицај на књижевна и идејна кретања у двадесетом веку какав је имао Николај Берђајев. На његову студију Ново средњовековље (1924) често ће се позивати у својим романима и српски постмодернисти, рецимо Светислав Басара. Полазећи од тезе да у историји, као и у природи, постоји ритам смењивања периода, Берђајев ново доба која се рађа након Великог рата и Октобарске револуције, одређује као почетак новог средњовековља. Након епохе која је била у знаку рационализма, просветитељства, разједињености, декаденције и губитка духовног центра, Берђајев види назнаке колосалног и спасоносног повратка неким средњовековним или, метафорично речено, ноћним метафизичким и онтолошким исходиштима:

„Падају лажне копрене, разголићује се добро и зло. Ноћ није мање лепа него ли дан, није мање божанска. У ноћи јарко светле звезде, у ноћи бивају откровења, којих не зна дан. Ноћ је првозданија, стихијнија него дан. (...) Ноћ је метафизичнија, онтологичнија од дана" (Берђајев 1990: 8-9).

Позивајући се подједнако и на Освалда Шпенглера колико и на руске песнике Андреја Белог и Фјодора Тјутчева, Берђајев као кључне средњовековне вредности истиче пуноћу бивства, богату симболку културе, сврсиходност живота, охристовљени универзум, мистицизам и чежњу за небом. Из данашње визуре јасно је да су друштвима формираним током двадесетог века знатно ближа похлепа, десакрализација или препуштање потрошачком „благостању". Међутим, Берђајевљева критика модерног света у име афирмације духовности, хришћанског хуманизма и емпатије не само да је актуелна више него икада раније него је у књижевности (пост)модерног доба налазила свој поетички легитимитет. 
Наративни интерес за средњи век може се у српском постмодернистичком роману пратити у распону од Пекићевог Времена чуда (1965) до Савршеног сећања на смрт (2008) Радослава Петковића. Сличне тенденције приметне су, већ раније, и у поезији: од Бранка Миљковића, Десанке Максимовић, Миодрага Павловића и Васка Попе до Ивана В. Лалића и Милосава Тешића. Интересовање за средњовековну, односно, ако говоримо о нашој књижевности, српско-византијску културу и духовност, одређујући је моменат историографске метафикције која, у одређењу Линде Хачион, није заснована само на тематизовању прошлости него и на ауторефлексивном преиспитивању приповедачког поступка, његових поетичких, сазнајних и етичких домета у репрезентовању историје (Хачион 1996). Питање како се приповедањем може досегнути и изразити историјска истина, разрешава сваки од постмодерних романописаца. Коначно, сваки од њих има специфичне разлоге зашто се окреће епохи средњег века.

Најинтригантије су, свакако, околности настанка Хазарског речника (1984) који је првобитно требало да буде научна студија о једном важном књижевном али и теолошком проблему из средњовековне историје. Нешто од тог научног усмерења и апаратуре Павићево дело је сачувало али преоденуто у постмодернистичко наративно „рухо”. Управо та поетичка веза између науке и фикције препознатљиво је обележје енциклопедијског романа, поготову у оном значењу које је овом жанру половином седамдесетих година прошлога столећа дао Едвард Менделсон (Менделсон 1976).

Након предавања које је одржао у Друштву за упоредну књижевност, неколико година након објављивања Хазарског речника, Павићу је упутила питање једна од наших најзначајнијих медијевалиста, Радмила Маринковић - да ли у његовом роману има и неких научних резултата? Павић је, са нешто дужом задршком, у једном каснијем тексту покушао да одговори. Пре него што је и помислио да би могао да напише такав роман, бавио се, као историчар књижевности, решењем дилеме о којој у стручној литератури није налазио задовољавајући одговор. Радило се о питању сукоба иконобораца и иконобранитеља у Византији током деветог века и посебно „иконокластичког одгоја и идејно-теолошке усмерености против култа икона код словенских апостола Ћирила и Методија" (Павић 1989: 638). Бављење животом солунске браће Павића је довело до њихове хазарске мисије и хазарске полемике, што га је даље упутило на најзначаније средњовековно сведочанство о овом догађају, Къигу о Хазарима (Kitab Al Khazari) шпанског јеврејског песника и религиозног филозофа Јуде Халевија. Временом је од студије из упоредне историје религије настао роман-лексикон о односу три религије. Колико је ово питање из византијске повести, теологије и уметности било важно Павићу као историчару и као књижевнику, сведочи и његова студија „Венцловић о иконокластичким борбама у Византији”, објављена у књизи Историја, сталеж и стил (1985). Анализирајући једну беседу коју је Гаврил Стефановић Венцловић 1741. године унео у свој Великопостник, Павић се детаљније задржава на теолошким расправама вођеним у Византији током VIII века. У њима је значајну улогу имао цар Константин V, ожењен хазарском принце- 
зом, а потом и његов син Лав IV, назван „царем од Хазарије”. Уз позивање на истраживања Григорија Острогорског и Димитрија Богдановића, Павић закључује да је сукоб иконобораца и иконобранитеља у крајњем исходу довео до учвршћивања христолошке догматике, као и да су његовом разрешењу извесну, посредну улогу имали и Хазари.

Иако овај сукоб нема важније место у Хазарском речнику, он је заправо метафорично уписан не само у средњовековном временском и смисаоном плану романа него и у његовој целини. Реч је о сложеним односима религија и јереси, светих књига и апокрифа, црквене догме, с једне, и окултних, езотеричних и мистичних знања, с друге стране. (В. о томе: Радуловић 2012; Олах 2012). Личности које трагају за истином о Хазарима само су једним делом представници званичних религија из којих долазе. Да би успели у својој намери они, како истиче Павић у једном интервјуу, „морају да буду мало померени, да иду на неку јеретичку страну од ортодоксије своје религије" (Павић 1990: 62). Тако се код Аврама Бранковића уочавају интересовања за патаренска, богумилска и, уопште, претхришћанска учења и традиције. Јеврејски хроничар Самуел Коен однегован је на кабалистичкој литератури, а познате су му и основе есенских учења. Слично је и са Јусуфом Масудијем, који прати јеретичку нит у арапској херметичкој традицији, поготову ону везану за медицинске вештине.

У Хазарском речнику, понајпре у његовом средњовековном слоју, успоставља се колосални распон од неба, преко земље до доњег света, односно од визије света какву нуде свете књиге од оне која се образује у апокрифним и езотеричним учењима. Истина за којом трагају јунаци не може се сагледати без њеног одраза у огледалу. На варљивом и тешко проходном путу до ње човекови сапутници су подједнако и божја промисао колико и демонска бића која га искушавају или нуде помоћ. Поред богатства средњовековне имагинације (снови, чуда, симболика бројева, хумор) роман тематизује и развија неке за то доба карактеристичне херменеутичке стратегије тумачења света и текста, а то је на првом месту алегореза. У „Зеленој књизи”, у одредници посвећеној Ал Бекрију, арапском хроничару хазарске полемике који је живео у XI веку, приповеда се и о нивоима значења Божије књиге: први је дословни, доступан сваком човеку; други ниво је алузивни и разуме га друштвена елита; трећи обухвата окултна знања, мистику, симболику бројева; коначно, четврти слој је пророчки и тиче се спознања будућих догађаја. Јунаци романа, а на њиховом трагу и читаоци, пробијају се кроз ове нивое покушавајући да разумеју смисао велике књиге света. Неке одрединице из средњовековног слоја Хазарског речника, попут оних о Ћирилу или Јуди Халевију, добар су пример како се Павићево приповедање одвија у знаку историографске метафикције, односно оног њеног наративног интереса који је најбоље изразио Данило Киш у једној од напомена на крају Енизиклопедије мртвих: „Прича је почела да се развија управо на местима где су подаци били недовољни а факта непозната, у полумраку где ствари задобијају повремене сенке и облике” (Киш 2007: 175). Дакле, тек ангажовањем књижевне имагинације, а то значи и поетичке и етичке самосвести, могуће је спознати прошлост у свој њеној пуноћи. 
Иако се ниједно књижевно дело не може упоредити са размерама универзалног смисла и јединства успостављеног у Библији, ово питање односа фрагмената према целини, могућности да стилска, жанровска или наративна хетерогеност ипак успоставља поетички промишљену композициону целину, важно је за одређење енциклопедизма подједако у античкој колико и у савременој књижевности. Тако француски критичар Франсоа Лефевр ово питање поставља поводом Хазарског речника, констатујући да динамични однос или игре фрагментарности и јединства суштински обележава романе као што су, поред Павићевог, и Живот, упутство за употребу (1978) Жоржа Перека или Историја света у 10 1/2 поглавља (1989) Џулијана Барнса. „Павићев роман нуди двоструку особеност: он је у исти мах вишеструк и јединствен. Веома сложено јединство крије се испод привидне дисперзије” (Лефевр 1997: 274). Као што постоје поетички, епистемолошки и онтолошки разлози зашто јединствена и континуирана прича више није могућа, што доводи до мултиплицирања наративне форме на жанровском, стилском или графичком плану, тако постоји и изазов, који прераста у ултимативни захтев, упућен читаоцу да од фрагмената реконструше изгубљену целину приче, односно света. Од Библије, чији је смисаони тоталитет загарантован фигуром месије, до фрагментарности савременог романа у којем је свака целина потенцијална, варијабилна и загарантована приповедачевим умећем и читалачком вољом, може се пратити поетичка линија сачињена од делаิ која сложеном приповедачком структуром и богатом ерудицијом конституишу визију света као мреже многоструких сазнајних и значењских односа. Међутим, ако прихватимо да је управо енциклопедички поетички модел оно што повезује одређене књижевне текстове настајале у распону од библијских времена од савременог доба, да ли се онда може изнаћи довољно свеобухватно одређење саме енциклопедичности које би имало универзални смисао? Иако би на ово питање најсигурније било дати уздржан одговор, чини се да би се ипак могло наћи полазиште за разумевање енциклопедизма које не би било у спору са специфичностима књижевности и културе у одређеним епохама. Трагајући за одговором шта је то што повезује библијско искуство приповедања са техникама модерних романа какви су Џојсов Уликса или Пинчонова Објава броја 49, Френк Кермод даје овакав закључак:

„Ако постоји неко веровање (ма колико оно некада било супротно чињеницама) које нас све уједињује, од евангелиста до оних који одбацују делове библијских текстова који им не одговарају и оних који смишљају компликоване приче како би неподударности и дисонанце уклопили у неку обимнију структуру, онда је то уверење да је на неки тајанствени начин све у свету повезано" (Кермод 1979: 131).

Наравно да то убеђење није одлика само оних дела које бисмо назвали енциклопедијским, али чини се да управо у тим остварењима идеја о бескрајној, и често неочекиваној, испреплетаности збивања и појава има своју пуну поетичку реализацију и читав спектар приповедачких консеквенци. Ово веровање изворно припада митском мишљењу према којем је „све целина, све повезано и сачињава космичко јединство” (Елијаде 2011: 197). 
Успостављање смисаоних аналогија између временски удаљених догађаја, ликова и знамења има у српском постмодернизму свој поетички врхунац у роману Опсада иркве Светог Cnaca (1997) Горана Петровића. То је у исти мах и врхунац енциклопедијског идеала инспирисаног средњовековном визијом сакралног и хијерархијски уређеног универзума. Дакле, не само да роман тематизује бурна историјска збивања - налазећи документарно упориште, између осталог, и у житијима краљева Драгутина и Милутина архиепископа Данила II - него и сама визија света, заснована на бројним симболима, фигурама и знамењима, почива на богатој средњовековној духовности. То је видљиво већ у композицији Петровићевог романа подељеног у четрдесет дана организованих у девет књига. Подела на дане, односно поглавља, заснована је на библијској и православној симболици броја четрдесет док књиге упућују на небеску хијерархију анђела коју је у раном средњем веку описао ПсеудоДионисије Ареопагита. У корпусу текстова који се приписују овом свецу (такозвана Аеропагитика) свет је описан као уређени универзум, као структура која почива на „закономерном субодређењу чулног и натчулног, хијерархија стално постојећа у ванвременској вечности" (Аверинцев 1982: 119). Међутим, такав поредак света у Петровићевом роману успоставља се и потврђује кроз стална искушења, опсаде, суочавања са злом, управо по моделу какав постоји у народним бајкама или средњовековним житијима, која опет реферишу на Христова искушења, муке и васкрсење. Три историјска догађаја, три опсаде, сижејна су језгра приче: четврти крсташки поход и пад Цариграда почетком XII века, разарање манастра Жиче крајем XIII века и НАТО бомбаровање Републике Српске на измаку XX века. Ова временски удаљена дешавања симултаним приповедањем се изводе из историјског, хронолошког следа и измештају у поредак етичке и смисаоне свевремености, односно онога што Аверинцев назива „ванвременском вечношћу”, где се непрестано одвија борба добра и зла у којој се хуманистичке вредности потврђују кроз супротстављање силама историјског разарања. Ова концепција времена у Опсади иркве Светог Спаса истакнута је одређеним знамењима која у структури романа добијају функцију иманентно поетичких фигура. Таква су четири чудесна прозора које из Никеје у Жичу доноси Сава Немањић, кроз која се из исте просторије, манастирске припрате, може гледати у прошлост, садашњост и будућност. Свети Петар на небу управља протоком времена окрећући пешчане сатове, прашчанике, који одређују универзални ритам историјских и космичких кретања.

Богата имагинација Петровићевог романа произилази и из још једне, у средњем веку изразито развијене симболике која ће постмодернизму бити посебно блиска - слици света као велике књиге. Како то Роберт Курцијус подробно прати и у западним и у источним, византијским, изворима представа о свету и природи као књизи има библијску заснованост и најпре је развијена у проповедничкој реторици, потом је преузета у мистичко-филозофској спекулацији и, коначно, прешла у ширу језичку употребу (Курцијус 1996: 522-534). Јунаци романа крећу се кроз простор као кроз приче док се кумански поход који прети манастиру „ближио се немо, као језовита ћутања” (Пе- 
тровић 2013: 113). Свет траје док постоје приче о њему а највеће казна која некога може да снађе је да буде протеран из сваке приче. На почетку света је божија реч и све што постоји настало је реализовањем и опредмећивањем речи и прича. Тако се историја одвија као борба добрих и злих речи - док монаси снагом молитве успевају да манастир уздигну на небо, дотле венецијански дужд Енрико Дандоло својом демонском речју наводи крсташки поход на разарање византијске престонице. Заправо поетичка окосница Петровићевог романа заснована је на перформативној снази језика коју је истакла новија лингвистика, односно прагматика, а коју је даље преузела и књижевни легитимитет јој дала теорија могућих светова. Међутим, уместо на теоријске поставке, роман се радије позива на домете средњовековне уметности и знања, рецимо из домена хералдике и орнитологије. Прича о томе да „свака реч има своје перо" (Петровић 2013: 58) важно је поетичко и сижејно упориште романа, од пада Цариграда због похлепе венецијанског дужда до урушавања балканских екосистема под бомбама нових завојевача.

Док је у роману Горана Петровића изразита сакрална слика средњег века, у прози Светислава Басаре она је, бахтиновски речено, карневалска. Видно је то у енциклопедијски успостављеном роману-алманаху Фама о бициклистима (1989) који отпочиње повешћу о Карлу Ружном, заснованој на бројним анахронизмима и мистификацијама, односно на разноврсним облицима постмодернистичког лудизма. Као што Карло своје краљевство види као азил за све јеретике, ,јер ако су сви људи грешни, нико не зна Бога, свака теологија је јерес. Кратко и јасно" (Басара 2005: 16), тако је и Фама уточиште за разне апокрифне и алтернативне визије историје, идеолошка учења и филозофске концепције, које су углавном пародије званичних, догматских и тоталитарних истина. Међутим, само је на први поглед у Басарином роману све плод хумористичке, карневалске имагинације која претендује да демаскира озбиљну, догматску историографију. У „Предговору приређивача” Фаме о бициклистима истиче се да истину више не вреди тражити у библиотекама Вавилона јер она је тамо похабана и овештала од употребе, односно како се то вели у цитату Николаја Берђајева, тамо је „дух објективисан, окамењен, повезан са палошћу света и разједињеношћу његових делова" (Басара 2005: 9). Тумачења историје у Басариним романима често су у знаку ритмичног смењивања епоха и периода који је у Новом средњовековљу описао Берђајев. У том смислу и слика средњег века је знатно слојевитија и проткана бројним цитатима и реминисценцијама на хришћанске свете оце или филозофе новијег доба. Да је Басарино приповедање опседнуто бројним онтолошким и есхатолошким питањима, сугерисано је у Фами и Кафкиним афоризмом који је узет као мото: „Месија ће доћи онда када више не буде потребан. Он неће доћи последњег. Доћи ће најпоследнијег дана." Гротескни светови Басарних романа као да вапе за избављењем од онтолошке беспомоћности, али спасења нема. У роману Уклета земља (1995) смех се указује као могућност да појединац сачува своје достојанство и хуманизам, јер „што се више будемо смејали то ћемо мање пропасти" (Басара 2014: 144). Међутим, осим смеха у Басарином приповедању често исијавају и етички тонови засновани 
на хришћанским вредностима и образложени у средњовековној теологији, која опсегом својих космолошких визија, метафизичких и егзистенцијалних разматрања често вишеструко превазилази оквире модерне филозофије. Тако се различити приповедачи и приређивачи у Уклетој земљь позивају на Светог Августина или Исака Сирина налазећи у њима морално и смисаоно упориште пред гротескним дешавањима новијег доба. Модерни свет тоне у хаос из кога је настао зато што се одрекао Бога: „Настао из хаоса, овај свет се, пошто није хтео да се уздигне Богу, враћа у хаос" (Басара 2014: 27). Повратак средњовековној духовности у Басариним романима није у знаку загледаности у византијску историју и уметност колико у теологију, подједнако источну колико и западну, која је свет тумачила као сврсисходни универзум, истичући етичке и духовне вредности као путоказе спасења. Занимљиво да у једном интервјуу с краја осамдесетих година Басара, не без ироније, назива себе теологом: „Како сам ја, упркос раширеној фами да сам писац, само теолог који у недостаку интересовања публике за теологију прибегава литератури, морао сам се послужити формом приче" (Басара 1989: 63).

Дијалог са монументалном средњовековном традицијом наставља се и у овом веку о чему речито сведочи роман Радослава Петковића Савршено сећање на смрт (2008). Ово дело је, може се то с пуним правом рећи, врхунац интересовања новије српске прозе за визатијско духовно наслеђе - филозофско, теолошко и уметничко. Иако има јасно опцртане историјске оквире везане за опсаду и пад Константинопоља, од 1422. до 1453. године, роман продире још дубље у повест хиљадугодишњег царства тежећи да, у облику својеврсне велике књиге знања, прикупи у целину нити источне духовности: од старозаветних и новозаветних текстова, античке неоплатоничарске филозофије, магијских учења и ониричких култова, житија и апокрифа. У препознатљивом постмодернистичком укрштају историјских извора и личности са фикционалним могућим световима и јунацима, Петковићев роман обликује широку панораму царства у тренутку кризе и урушавања, када се званична религија постепено уклања пред древним мистичним спознајама. У великим историјским и идеолошким кризама колективна свест и индивидуална имагинација имају потребу за повратком традицији и националном идентитету али и за легитимисањем нових истина, спознаја и вредносних система. У том, смислу роман би се могао читати као повест о зачецима европске херметичке езотерије на измаку средњег века и почетком ренесансе, у чему су важну улогу имали византијски филозофи - какав је у овом роману Плитон, представљен и као могућа реинкарнација Платона - који су Запад упознали са античким, хеленским али и оријенталним знањима што их је баштинило пропало источно царство.

Међутим, важно је приметити да је годину дана пре романа Савршено сећање на смрт Радослав Петковић објавио есејистичку књигу Византијски интернет (2007), која би се могла схвати као историјска, научна па и аутопоетичка пролегомена за читање романа. Приповедајући више као историчар а мање као романописац, Петковић у овој књизи преиспитује знања, предрасуде и заблуде које имамо о држави за коју се усталило име Византија. Заправо 
империја под таквим именом никада није постојала. Њени житељи, владари, уметници и мислиоци себе су сматрали настављачима Римског царства па су своју државу тако и звали. Назив који ми данас користимо настао је у шеснаестом веку и био је у вези са политичким настојањима тадашњих западноевропских владара и историчара да славу и моћ империјалног Рима присвоје само за себе. Већ ова „игра именовања” открива много о томе колико су наше представе о средњем веку, чак и данас у доба интернета, варљиве и проблематичне. Тога постаје свесна управо српска постмодернистичка историографска метафикција која зна да „оргомна површина историје ни изблиза не казује онолико колико скрива њена мрачна утоба” (Петровић 2013: 152).

\section{ИЗВОРИ}

Басара 1989: С. Басара, Феномени, Титово Ужице: Вести.

Басара 2005: С. Басара, Фама о биииклистима, Београд: Завод за уџбенике.

Басара 2014: С. Басара, Уклета земљь, Београд: Лагуна.

Киш 2007: Д. Киш, Енциклопедија мртвих, Београд: Просвета.

Павић 1988: М. Павић, Хазарски речник, Београд: Просвета.

Павић 1989: М. Павић, „О Хазарском речнику”, Сриска фантастика, зборник радова, ур. П. Палавестра, Београд: САНУ.

Павић 1990: М. Павић, Хазари или обнова византијског романа, Београд: Српска књижевна задруга.

Петровић 2013: Г. Петровић, Oncaда иркве Светог Cnaca, Београд: Вулкан издаваштво.

Петковић 2007: R. Petković, Vizantijski internet, Beograd: Stubovi kulture.

Петковић 2008: Р. Петковић, Савршено сећање на смрт, Београд: Лагуна.

\section{ЛИТЕРАТУРА}

Аверинцев 1982: С. Аверинцев, Поетика рановизантијске књижевности, прев. Д. Недељковић, М. Момчиловић, Београд: Српска књижевна задруга.

Берђајев 1990: Н. Берђајев, Ново средњовековље, прев. Н. Талер, Београд: Хипнос.

Велш 2000: В. Велш, Наша модерна постмодерна, прев. Б. Рајлић, Сремски Карловци, Нови Сад: Издавачка књижарница Зорана Стојановића.

Делић 1991: J. Delić, Hazarska prizma: tumačenje proze Milorada Pavića, Beograd: Prosveta.

Еко 1965: U. Eco, Otvoreno djelo, prev. N. Milićević, Sarajevo: Veselin Masleša. Елијаде 2011: M. Elijade, Rasprava o istoriji religija, prev. D. Janjić, Novi Sad: Akademska knjiga. 
Кермод 1979: F. Kermode, The Genesis of Secrecy: On the Interpretation of $\mathrm{Na}$ rrative, Harvard University Press.

Курцијус 1996: Е. Р. Курцијус, Европска књижевност и латински средњи век, прев. Ј. Бабић, Београд: Српска књижевна задруга.

Лефевр 1997: Ф. Лефевр, „Читање Хазарског речника Милорада Павића”, Кюижевност, бр. 1-2.

Менделсон 1976: E. Mendelson, „Encyclopedic Narrative: From Dante to Pynchon", MNL, Vol. 91, No.6, pp. 1267-1275.

Олах 2012: К. Олах, „Инверзна апокалипса. О проблему јереси и културном (само)одређењу Хазарског речника Милорада Павића", Зборник Матиие српске за књижевност и језик, год. 60, бр. 2, стр. 461-489.

Павић 1985: М. Павић, Историја, сталеж и стил, Нови Сад: Матица српска. Радуловић 2012: Н. Радуловић, „Између игре и иницијације. Павић и наслеђе европског езотеризма", Зборник Матице срспке за књижевност и језик, год. 60, бр. 2, стр. 437-461.

Скарпета 2003: Г. Скарпета, Повратак бароку, прев. П. Секеруш, Нови Сад: Светови.

Хачион 1996: L. Hačion, Poetika postmodernizma, prev. V. Gvozden, Novi Sad: Svetovi.

Predrag Ž. Petrović

MEDIEVAL SPIRITUALITY AS BASE OF POSTMODERN ENCYCLOPEDISM

(Summary)

Starting from the theoretical considerations of Umberto Eko and Nikolai Berdayev, the text examines the presence of medieval spirituality in some of the finest Serbian postmodern novels: The Khazar Dictionary by Milorad Pavić, The Cyclist Conspiracy by Svetislav Basara, The Siege of the Church of Saint Salvation by Goran Petrović and A Perfect Memory of the Death by Radoslav Petković. Although the relationship to the Middle Ages is different for each of these authors, it in no way boils down to a thematic, but rather reveals a more complex creative tendency to establish the image of the world as a meaningful totality. The question of how storytelling can reach and express historical truth is resolved by each of the postmodern novelists. Finally, each has specific reasons why it is turning to the Middle Ages. 